eruption of repeated differentiation cycles of basic and alkaline volcanic rocks.

During his life-time Benson received many honours. $\mathrm{H}_{\theta}$ was a foundation Fellow of the Australian and New Zealand Association for the Advancement of Science, and its Mueller Medallist (1951); Fellow of the New Zealand Institute, later Royal Society of New Zealand (1926); Hector medallist (1933), Hutton medallist (1944) and president (1945-47) of the same Society; Lyell medallist of the Geological Society (1939); Fellow of the Royal Society (1941); Clarke medallist of the Royal Soeiety of New South Wales (1945); correspondent of the Geological Society of America (1949); honorary D.Sc., University of New Zealand (1951), and honorary member of the Mineralogical Society (1954).

Benson looked upon himself as a goological child of Sir Edgeworth David, and he always spoke of his old chief with the greatest reverence and affection. There is now another geological family, that of W. N. Benson himself, whose members are spread throughout the world. He has left them-and science as a wholewell over a hundred published memoirs, papers and notes recording his researches and his scientific philosophy, written in his own characteristic style. Above all he has left them the memory of himself, which lives on in the ever-widening circle of his geological descendants.

$\mathrm{He}$ is survived by his wife, formerly Miss Helen Rawson, who was professor of home science in the University of Otago at the time of their marriage in 1923.

D. S. Coombs

\section{Dr. Charles Todd, O.B.E., F.R.S.}

Charles Todd died at Croydon on September 22. $\mathrm{He}_{\Theta}$ was born in 1869 , coming of farming stock in Cumberland. After ill-health as a small boy, he received an education, mainly classical, at Carlisle Grammar Sehool, but succeeded in obtaining an open scholarship in physics and chemistry at Clare College, Cambridge, in 1888. In due course he obtained a Class I in the Natural Science Tripos, proceeding to St. Bartholomew's Hospital with an open scholarship and qualifying in 1894. After several elinical appoint ments he became interested in public health problems while working at the London Fever Hospital. In 1900 he became assistant bacteriologist to the serum department of the Lister (then Jenner) Institute and worked on antitoxins with George Dean and later G. F. Petrie. Here he demonstrated the existence of a toxin produced by Shiga dysentery bacilli. $\mathrm{He}$ went to Egypt in 1904 to help to make antisera against cattle plague, of which there was a serious outbreak there. This led to an appointment as bacteriologist and afterwards director of the Hygienic Institute in Cairo, and he finally spent twenty-one years in Egypt. In 1906 he was investigating scorpion venom and found out how to make an antiserum. But cattle plague remained a major interest and he made valuable contributions to our knowledge of the disease.

His most important scientific work arose incidentally out of this, for, with R. G. White, he found that cattle repeatedly injected with virulent blood developed isolysins in their sera. The cellular individuality of cattle thus came to light : and Todd and White showed that with suitably absorbed sera the blood cells of any individual could be distinguished from those of any other.
In 1925 'Todd left Egypt, having worked on many aspects of public health and received many honours. In 1926 he was given a research grant to work at the National Institute for Medical Research at Hampstoad. Here he continued his studies on cellular individuality, now using fowls, in which isohæmagglutinins were readily produced. As with cattle, he found that with absorbed sera he could pick out bloods of individual fowls. He went further and determined that the immunological specificity was inherited: polyvalent sera absorbed with colls of both parents had no action on the cells of their chicks.

At Hampstead Todd worked also on fowl plague and described a 'dilution phenomenon' in which just neutral serum-virus mixtures had their activity restored by dilution. With Perdrau he made studies of the photodynamic action of methylene blue on bacteriophage and other viruses. He finally rotirod in 1940 .

Todd was a delightful and helpful colleague with a great zest for life and a wonderful sense of fun. $\mathrm{He}$ had a wide knowledge of public health and microbiology and knew not a little about physics. He delighted in 'Heath-Robinson' gadgets, had a very critical mind and scorn for pretentiousness. He was elected Fellow of the Royal Society in 1930. $\mathrm{H}_{\Theta}$ was unmarriod.

C. H. Andrewes

\section{Dr. R. O. Page}

Wrth the death of Robin O. Page, which occurred on July 14 in Christchurch, Now Zealand, the science of leather chemistry has suffered a heavy loss. Robin Page was born in 1897 at Christchurch, New Zealand, which was to become his residence for the rest of his life. During his college years he distinguished himself as a scholar and in various sports; he even represented his country in athletics. After receiving the master's degree with first-class honours in chemistry at University College, Canterbury, in 1920, he joined the staff of Woolston Tanneries, Ltd., Christchurch, as a chemist. $\mathrm{He}$ was appointed works manager in 1924-a position which ho held up to his death.

At an early age he was fascinated by the intricate problems of the mechanism of tanning reactions; an interest which followed him all through his active life. To his inquiring mind the fundamentals and theoretical concepts were vital exigencies. In addition to carrying responsibility in the industry, Page not only kept himself informed about current scientific progress but also contributed a distinguished series of more than twenty original papers-the result of the research which he carried out alongside his practical duties for the love of the great unknown of his 'bread and butter' reactions.

Page was one of the first investigators to realize the importance of the physico-chemical approach in the elucidation of tanning processes, being inspired by the new ideas of the early 'twenties, propounded by Jacques Loeb and John Arthur Wilson, on the behaviour of proteins. This is shown by his lucid papers on ion effects on collagen published in 1927. The subsequent main contributions of Page concern the mechanism of the vegetable tannage. With his sound conception, thorough knowledge of chemistry and critical outlook, the tannery experience became to him a solid background for these pioneering investigations. Among his more recent publications, his clarifying investigation of the classical tannin- 
gelatin reaction-first studied by Humphry Davy in 1803 - should be especially mentioned for its explicity of technique and sound theorization. These papers, published in British and American journals, made Page an outstanding figure in contemporary leather research.

His scholarly endeavour was early recognized, not only by his own colleagues. Thus, the University of New Zealand conferred the degree of D.Sc. upon him in 1934. Dr. Page took an active part in the scientific life of his own country, being a Fellow of the Royal Institute of Chemistry, a Fellow of the New Zealand Institute, also a past president of that body, and a Fellow of the Royal Society of New Zealand. During overseas visits to Europe and the United States he made many friends. The man and his achievoments carried the imprint of sterling qualities.

K. H. Gustavson

\section{NEWS and VIEWS}

\section{Royal Society Medal Awards}

THE following awards of medals have been made by the President and the Council of the Royal Society: Copley Medal to Sir Howard Florey, professor of pathology in the University of Oxford, for his distinguished contributions to experimental pathology and medicine; Davy Medal to Dame Kathleen Lonsdale, professor of chemistry at University College, London, for her distinguished studies in the structure and growth of crystals; Buchanan Medal to Sir Neil Hamilton Fairloy, for his distinguished contributions to the control of malaria; Hughes Medal to Prof. J. Proudman, professor emeritus of oceanography in the University of Liverpool, for his distinguished work on dynamical ocoanography.

Royal Society of Edinburgh : Officers for 1957-58

THE following have been appointed to the Council of the Royal Society of Edinburgh for the session 1957-58: President, Prof. James Ritchie; VicePresidents, Prof. J. Norman Davidson, Principal H. B. Nisbet, Prof. Meirion Thomas, Prof. A. C. Aitken, Dr. J. E. Richey and Prof. D. Whitteridge; General Secretary, Prof. Norman Feather; Secretaries to Ordinary Meetings, Dr. T. R. Bolam, Dr. A. W. Greenwood; Treasurer, Dr. J. R. Peddie; Curator of Library and Museum, Dr. Douglas Guthrie; Councillors, Dr. D. A. Allan, Prof. G. H. Bell, Dr. D. N. McArthur, Dr. A. G. MacGregor, Prof. C. H. Waddington, Dr. J. A. Macdonald, Dr. R. Schlapp, Dr. J. B. Tait, Prof. G. M. Wyburn, Prof. R. A. Rankin, Prof. A. E. Ritchie and Prof. W. M. Smart.

\section{Royal Society of South Africa : Elections}

THe following have recently been elected to fellowship in the Royal Society of South Africa: Dr. R. A. Alexander, director of veterinary services, South Africa, Onderstepoort, Pretoria; Dr. J. J. Frankel, Dopartment of Geology and Mineralogy, University of Natal, Durban; Prof. I. Gordon, professor of pathology and dean of the Medical Faculty, Medical School, Durban; Prof. F. G. Holliman, professor of organic chemistry in the University of Cape Town; and Dr. R. H. Marloth, director of the Citrus and Subtropical Horticultural Research Station, Nelspruit, Transvaal.

\section{Organic Chemistry at Glasgow :}

\section{Prof. R. A. Raphael}

The appointment of Ralph Alexander Raphael to the regius chair of chemistry at Glasgow brings him back to the University where he held a lectureship during 1949-54. He graduated from the Imperial College of Science and Technology, London, in 1941 , with first-class honours, and obtained the Ph.D. degree in 1943. Aftor a period with Messrs. May and Baker, Ltd., he returned to the Imperial College in 1946 with an Imperial Chemical Industries Followship. His distinction as an organic chomist won early recognition when he was awarded the Meldola Medal for 1948 at the age of twenty-seven. His main interest in research has been the study of acetylenic compounds and, in particular, the use of such reagents as precursors in the synthesis of a wide range of naturally occurring organic substances. In 1954, Dr. Raphael became the first professor of organic chemistry at The Queen's University of Belfast. The combination of his skilful leadership and his enthusiastic personality led to a rapid expansion of the research school in organic chemistry during his throe years at Queen's ; his outstanding success there as a teacher and as a director of research augurs well for the future of organic chemistry in Glasgow.

\section{Organic Chemistry at Belfast :}

Prof. H. B. Henbest

THE appointment of Dr. H. B. Henbest to the chair of organic chemistry at The Queen's University of Belfast, in succession to Prof. R. A. Raphael, certainly represents an example of a meteoric rise. Graduating with first-class honours at the Imperial College of Science and Technology, London, in 1944, he worked under Prof. (then Di.) E. R. H. Jones, a collaboration he was enabled to continue after his doctorate by the award of a Beit Research Fellowship. Henbest accompanied Jones to Manchester on the latter's appointment to the chair in 1948, and remained there as a lecturer in organic chemistry until 1956 ; this was punctuated by a year's leave of absence, during which he worked at Harvard and the University of California, Los Angeles. Only shortly before the appointment to Queen's he had moved to King's College, London, as reader in organic chemistry.

The outstanding impression of Henbest's research work is its lack of triviality and its concentration on important and live topics. His first conjoint project was the establishment of an improved route to provitamin $\mathrm{D}_{3}$, and, continuing his steroid interests, he played a large part in devising a new route to cortisone from ergosterol. Another outstanding achievement in the vitamin field was the establishment of the structure of vitamin $\mathrm{A}_{2}$ by an unambiguous synthesis. A logical extension of interest to plant homones led to synthetic work in relation to the postulated structure of auxins $a$ and $b$, and to the isolation and proof of structure of a new plant hormone, 3-indolylacetonitrile. Aspects of acetylene chemistry have also engaged his attention, leading, for example, to the synthesis of kawain. At prosent he is engaged on a series of highly original stereochemical investi- 